\title{
Effectiveness of Implementation of High Order Thinking Skills (HOTS) and Self Efficacy of Students in Improving Economic Literacy
}

\author{
Ambuy Sabur ${ }^{1}$, Dadang Saepuloh ${ }^{2 *}$, Siti Subaidah ${ }^{3}$, Deri Firmansyah ${ }^{4}$ \\ ${ }^{1}$ PPS Magister Administrasi Publik Universitas Islam Syekh-Yusuf, ambuysabur@unis.ac.id \\ ${ }^{2}$ FKIP Ekonomi Universitas Islam Syekh-Yusuf, dsaepuloh@unis.ac.id \\ ${ }^{3}$ Editor of PT Bidara Cendekia Ilmi Nusantara baidazamani@gmail.com \\ ${ }^{4}$ Akuntasi STIE PASIM, deri@ stiepasim.ac.id \\ ${ }^{*}$ Corresponding author. Email: dsaepuloh@unis.ac.id
}

\begin{abstract}
This research aims to analyze the effectiveness of HOTS learning and self efficacy of students on economic literacy, the population of grade XI SMAN 11 Tangerang city as much as 109, sampled using Proportionate Simple Random Sampling through sloven formula so as to be a sample number of 90 students. The result of his research is that together the effectiveness of HOTS learning and student self efficacy have a significant effect on economic literacy, The effectiveness of HOTS learning has a significant effect on economic literacy, Self efficacy of students has a significant effect on economic literacy.
\end{abstract}

Keywords: HOTS, self efficacy, economic literacy

\section{INTRODUCTION}

The 2018 Computer-Based National Exam has given rise to a new discourse in the test materials given to students. In economics lessons, the materials tested to further test students' competencies in economics, namely the ability of students to apply economic knowledge to solve the problems of daily life. No wonder that almost all test items tested contain a story or word problem. Here is a chart of the value of UN Economic the last four years in all districts of cities in Indonesia.

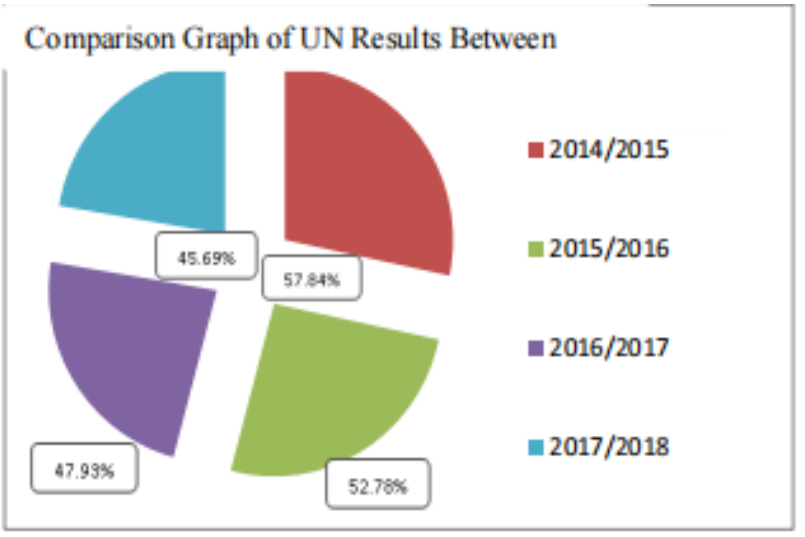

Source: processed by kemendikbud.go.id/hasilun/
Based on the UN high school scores of students in Indonesia over the last four years experienced a significant decrease of $12.15 \%$. This can also be seen from the average UN high school grades in the 2017/2018 school year, the fewer grades above 55.1 to 89.9 shown in the following chart.

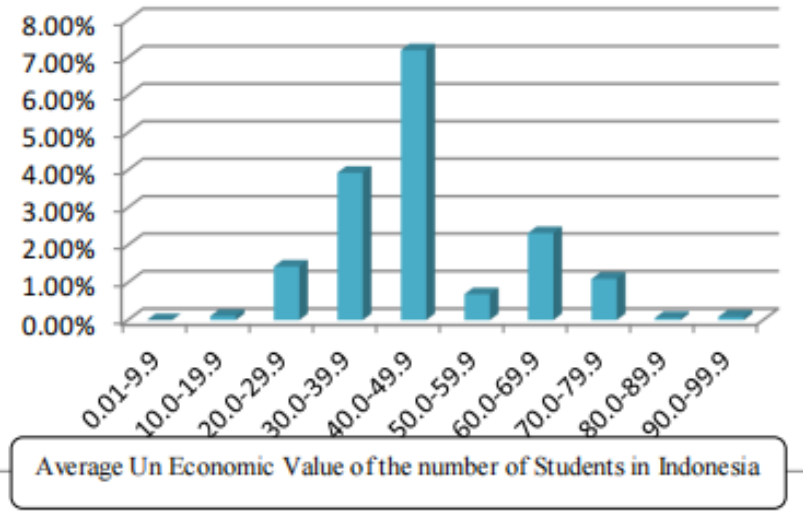

Source: processed by kemendikbud.go.id/hasilun/

Based on the chart above shows that students' economic scores in Indonesia from grades 55.1 to 89.9 are, on average, at $4.2 \%$, while grades 
0.01 to 59.9 are at an average of $12.67 \%$. From these results shows that the economic UN scores compiled based on HOTS high school students in Indonesia have not mastered the question correctly made so as to get low grades. After the exam was held, the Minister of Education and Culture in several media, such as Kompas (dated April 13, 2018) Minister of Education Muhadjir Effendy expressed an apology regarding the ComputerBased National Exam (UNBK) which was considered too difficult by the students of Junior High School (Junior High school and High School (SMA) quoted from Kompas Online daily https://nasional.kompas.com/read/2018/04/13/1752

5781. Then also through Antara media (13 April 2018), the Minister of Education promised to improve the system of implementation of national exams in the future. As for the reasons given by the Minister of Education the difficulty of the question tested at UNBK in 2018 aims to catch up with the (https://www.antaranews.com/berita/701141). The lag in question is the low results of two surveys of Indonesian students from the Program for International Student Assessment (PISA) mentioning, the literacy, culture of Indonesian society in 2012 was the second worst out of 65 countries studied in the world. Indonesia ranks 64th out of 65 countries. As well as the low economic literacy of people in Indonesia shown based on the national literacy index, the economy is still low at 8.11 percent, the survey was conducted in 2016 through OJK. Robert F. Duvall, President and CEO of the National Council on Economic Education (NCEE), "Economic literacy is an important skill, just as important as reading literacy." Having basic knowledge of economics (economic literacy), students can manage financially intelligently, let alone students still earn money from their parents so that students must properly understand the main needs that must be had as a student and be able to be rational. Students should be able to control the desire to buy irrational goods, Just as important as literacy reading, writing and counting, then financial literacy and economic literacy integrated factors in the economic literacy movement (Saepuloh D, Aisyah, 2020)
According to Peter Garlans Sina (2012) "For the creation of value crystallized in behavior requires economic literacy, because in principle economic literacy is a useful tool for changing behavior of an intelligent to intelligent. Such as how to utilize the income to save, invest, protect and meet the needs of life". Economic literacy is one of the factors that can affect welfare levels. So with economic literacy it is expected that students can learn to live frugally and can save first to get what they want. According to Tiryakian (in Sanggar Kanto 2011), This result was reinforced by Cole, Shawn \& Gauri Kartini S. (2009) in his research which found that there is a meaningful relationship between problem solving and self efficacy of literacy, as well as meaningfully related to metacognitive awareness. Integrative tasks are usually used as tools in scientific approaches, project based learning models, problem-based learning models, or discovery learning models. Innovative learning models capable of improving student self-efficacy, such as positive thinking training models are shown to have a significant influence to improve self-efficacy in students (Dwitantyanov, Hidayanti, Sawitri, 2010) In accordance with the theory of Bandura (1997) states that selfefficacy is an important component in making a great contribution to one's efforts, interests and perseverance. Self Efficacy helps students to act and change financial behavior in a better direction (Danes \& Haberman, 2007), In addition, the problem of economic rationality is necessary in order to build a good business. On an individual scale rationality affects the increase in household income as well as on a broader scale rationality affects the economic improvement that society has (NyomanTrisna Herawati, Made Candiasa 2018) As the results of the study suggested that students who have good self- efficacy will be able to improve productive behavior at work and in various areas of life in order to earn more income (Rheza Hafid Prastia, Sri Umi Mintarti W, 2017) This is similar in Kennedy's research (2013) which showed that self efficacy had a significant negative effect on credit card debt behavior in the economy. So based on the background that the author has described formulating the problem is:

1.1. Is there any effect of The Effectiveness of HOTS Learning Implementation on Economic Literacy of students in SMAN 11 Tangerang City? 
1.2. Is there an influence of Student Self-Efficacy on Economic Literacy in SMAN 11 Tangerang City?

1.3. Is there an effect of the Effectiveness of HOTS Learning Implementation and Student Self- Efficacy on Student Economic Literacy in SMAN 11 Tangerang City?

\section{RESEARCH METHODOLOGY}

The research method used in this study is an explanatory survey method through questionnaires that have been conducted validity and reliability tests. The population of this study is grade XI students SMAN 11 Tangerang city

as many as 109 , sampled using Proportionate

Simple Random Sampling through slovin formula so that it becomes a sample number of 90 students. Data analysis techniques use multiple linear regressions after going through analysis prerequisite tests.

\section{RESULTS AND DISCUSSIONS}

Before the authors conducted the hypothesis test in this study, the data presented was already through the prerequisite test of the analysis. Based on the results of data analysis conducted in this study, it can be explained through the table below

3.1 Double Correlation Coefficient, Coefficient. Determination, Effectiveness of HOTS Learning and Self Efficacy Together Against Economic Literacy Model Summary

\begin{tabular}{|c|c|c|c|c|}
\hline Model & $\mathrm{R}$ & $\begin{array}{l}\mathrm{R} \\
\text { Square }\end{array}$ & $\begin{array}{l}\text { Adjusted } \\
\text { R Square }\end{array}$ & $\begin{array}{l}\text { Std. } \\
\text { Error of } \\
\text { the } \\
\text { Estimate }\end{array}$ \\
\hline 1 & $.527^{\mathrm{a}}$ & 0.278 & 0.261 & 7.45259 \\
\hline
\end{tabular}

3.2 Double Correlation Coefficient Testing ANOVAb

\begin{tabular}{lllll}
\hline Model & df & $\begin{array}{l}\text { Mean } \\
\text { Square }\end{array}$ & F & Sig. \\
\hline Regression & & & & \\
& 2 & 930.412 & 16.752 & $.000^{\mathrm{a}}$ \\
\hline Residual & 87 & 55.541 & & \\
\hline Total & 89 & & & \\
\hline
\end{tabular}

a. Predictors: (Constant), self efficacy, effectiveness of HOTS learning

b. Dependent Variable: Economic literacy

3.2 Double Regression Coefficient Coefficients ${ }^{a}$

\begin{tabular}{|c|c|c|c|c|}
\hline Model & $\begin{array}{l}\text { Unstand } \\
\text { Coeffici }\end{array}$ & Error & Sig. B & Std. \\
\hline (Constant) & 13.045 & 9.852 & 1.324 & 0.189 \\
\hline $\begin{array}{l}\text { effectiveness of } \\
\text { HOTS } \\
\text { learning }\end{array}$ & 0.618 & 0.115 & 5.354 & 0 \\
\hline self efficacy & 0.22 & 0.098 & 2.24 & 0.028 \\
\hline
\end{tabular}

a. Dependent Variable: Economic literacy

\subsection{The Effectiveness of HOTS and Self Efficacy Learning Together On Economic Literacy of Economics}

From table 3.1. Above it appears that the double correlation coefficient of the influence of free variables on the effectiveness of HOTS (X1) and self efficacy (X2) learning together against economic literacy $(\mathrm{Y})$ is 0.527 . The calculation of the significance of

this double correlation coefficient can be seen in the significant sign (a) in column R. From that calculation, it is obtained that the correlation coefficient is significant, in other words, that there is a significant influence of variable-free learning effectiveness of HOTS (X1) and self efficacy (X2) together on economic literacy $(\mathrm{Y})$.

While the determination coefficient of $27.8 \%$ indicates that the contribution of the effectiveness of HOTS (X1) and self efficacy 
(X2) learning together affects economic literacy (Y) is $27.8 \%$, the remaining $(72.3 \%)$ because of the influence of other factors.

As for hypothesis testing through regression analysis obtained the calculation results are seen in Table 4.11. And Table 4.12., From Table 4.12. A regression line equation that represents the effect of variables $\mathrm{X} 1$ and $\mathrm{X} 2$ on variable $\mathrm{Y}$, i.e. $\hat{\mathbf{Y}}=\mathbf{- 1 3 , 0 4 5}+\mathbf{0 , 6 1 8 X 1}+$ $0,220 \times 2$.

While testing the significance of the regression line is to pay attention to the calculation results in Table 3.2. According to the existing provisions, the criteria of regression significance are "if $\mathrm{Sig}<0.05$ then $\mathrm{H} 0$ rejected" or "if the $\mathbf{F}_{\text {count }}$

$>$ Ftable then $\mathrm{H} 0$ rejected", which means that the regression coefficient is significant, in other words, there is a significant influence of free variables $\mathrm{X} 1$ and $\mathrm{X} 2$ on variables bound Y. Sig value is the number listed in the Sig column in Table 4.11. Value Fcount is the number listed in column $\mathrm{F}$ in Table 4.11. While the value of F table is the distribution table value $\mathrm{F}$ for the real level of $5 \%$ with the numerator degree $(\mathrm{k})=2$ and the denominator degree $(\mathrm{n}-\mathrm{k}-1)=87$ where $\mathrm{n}$ is the number of respondents, and $\mathrm{k}$ is the number of free variables.

From Table 3.2. visible that the value sig $=$ 0.000 and $\mathbf{F}$ count $=16,752$, While $\mathbf{F}$ table $=3,10$. Fcount > Ftable Then H0 Which means that the regression coefficient is significant. In other words, there is a significant effect of variable-free learning effectiveness of HOTS (X1) and self efficacy (X2) together on variables bound to economic literacy (Y). From the results of the correlation and regression test, it can be concluded that there is a significant influence of free variables on the effectiveness of HOTS (X1) and self efficacy (X2) learning together on variables bound to economic literacy $(\mathrm{Y})$.

\subsection{Effect on HOTS Learning Effectiveness on Economic Literacy}

Based on Table 3.2 above and the double regression equation shows that ho's statistical hypothesis: No influence of HOTS learning effectiveness variables (X1) on economic literacy variables $(\mathrm{Y})$ is rejected due to value tcount $=5,354$ and sig. $=0.000<0.05$. This means $\mathrm{H} 1$ is accepted. This means that the research hypothesis that states there is an effect on the effectiveness of HOTS learning on economic literacy variables is accepted.
Economic literacy is the ability to understand the meaning and meaning of economics, which is about human actions to meet the needs of life that varies widely and develops with existing resources through the choices of production, consumption and distribution activities realized with efficiency in the act of consuming (Widyayanti, 2009). Based on the results of research conducted by Salamon (2007) three proposed methods that can be used to improve the literacy skills of learning planning, learning activities process, and development of students' thinking skills during the learning process. Learning processes that fail to stimulate students' thinking and reasoning will cause difficulties for students to explore more complex problems because they focus only on memorizing facts and are tied to structured problem solving In addition, reliance on teachers can also lead students to gain knowledge only after going beyond remembering and memorizing levels towards higher cognitive levels. This has an impact on student literacy due to the failure to master higher order thinking skills and students will not be able to lead through an effective lifelong learning process (Aksela, 2005) HOTS Learning encourages students to develop knowledge in meaningful learning (King, 2008), As Anderson and Krathwohl (2001) have said, HOTS learning involves analyzing, evaluating, and creating skills, so HOTS learning encourages meaningful learning for students because they build knowledge through an active learning process and not just examples, but develop examples that are applied in everyday life (Bruner, 1966).

Based on the results of the analysis of the results of hots learning effectiveness research with economic literacy stated there is an effect of the effectiveness of HOTS learning on economic literacy variables this is similar to the results of research conducted by Latifah (2015) HOTS learning that is effectively done in the learning process can develop students' thinking beyond the level of understanding alone cognitively but able to develop at the applicative stage in daily life. In common with the results of Saepuloh and Rodiah research (2020) stated that the implementation of group investigation model through HOTS learning 
can improve economic literacy. This is natural because the better lecturers in whether it is using methods, curriculum mapping good learning media or innovative will definitely improve the economic literacy of students (Rafsanjani, 2019).

\subsection{The Influence of Self Efficacy on Economic Literacy}

Based on Table 3.3 above and the double regression equation shows that ho statistical hypothesis: No effect of self efficacy variables against (X2) on economic literacy variables $(\mathrm{Y})$ is rejected due to value tCount $=$ 2,240 and sig. $=0.028$

$<0.05$. This means H1 Accepted. This means that the research hypothesis that there is an influence of self efficacy on economic literacy is acceptable.

Good Self Efficacy will make self-control for students in conducting self-control to do economic activities well in a planned manner. This will help to always consider every economic activity, it does include the shopping process that makes the financial planning issued with the proceeds it gets later, so that they will only buy the goods they really need. Self Efficacy describes the true state of a person who will be able to control every impulse and emotional trait that is in him or her. The very important thing in improving one's economic literacy is that a good self-efficacy that is strengthened through confidence, self-control and strong consideration in the heart will have considerable influence, as it relates to how one controls himself, in the same way that Judi L. Postmus (2013) stated that students who feel confident are able to help themselves to grow and develop financially.

Based on the results of this study stated that there is an influence of student self efficacy on economic literacy, in consistent with the results of research conducted by Puspa Eka Widyawati (2019) stated that self efficacy has a significant and partially positive influence on student economic literacy, strengthened by the results of research stating that self efficacy affects faidah economic behavior (2018). Judi L. Postmus (2013) Argues that there is a positive relationship between Self Efficacy variables and financial literacy this is in line with his opinion of Amromin (2010), Jananti (2014). However, in contrast to the results of the research revealed by Partono Thomas (2016) that self efficacy does not affect financial literacy.

\section{CONCLUSION}

Based on the results and discussions in the previous chapter, it can be concluded that:
1. Together the effectiveness of HOTS learning and student self efficacy have a significant impact on economic literacy

2. The effectiveness of HOTS learning has a significant impact on economic literacy.

3. Self-efficacy of students has a significant effect on economic literacy.

\section{ACKNOWLEDGMENTS}

Thank you to Yayasan Shaykh-Yusuf through DKAT LPPM Universitas Islam SyekhYusuf, who has provided research funds for Lecturer

\section{REFERENCES}

[1] Aksela, M. (2005). Supporting Meaningful Chemistry Learning and Higher-order Thinking through ComputerAssisted Inquiry: A Design Research Approach. University of Helsinki.

[2] Amromin, G., Jennifer, H., Clemens, S., \& Edward, Z. (2010). Complex Mortgages. Federal Reserve Bank of Chicago Working Paper no. 2010-17, November 2010

[3] Bandura, A. 1997. Self-Efficacy (Efikasi Diri), (Online), (http://treepjkr.multiply.com/Reviews /item/22), diakses 12 April 2012)

[4] Christelis, et. al. (2009). Cognitive Abilities and Portpolio Choice., European Economic Review.

[5] Cole, Shawn \& Gauri Kartini S. (2009). Smart Money: The Effect of education, Cognitive Ability and Financial Literacy on Financial market participation. Harvard Business School Working paper. No. 09-071

[6] Danes,S.M \& Haberman,H.R. (2007). Teen Financial Knowledge, Self-Efficacy, and Behavior : A Gendered View. Financial Counseling and Planning, $18 \quad$ (2): 48-60. (online) Htpp://www.afcpe.org/assets/pdf/7- 2866-volume18-issue-2.pdf), (diakses tanggal 15 Juli 2015).

[7] Dwitantyanov, A., Farida Hidayati, dan Dian Ratna Sawitri. (2010). Pengaruh Pelatihan Berpikir Positif Pada Efikasi Diri Akademik 
Mahasiswa" Jurnal Psokologi Undip Vol.8, No.2, Oktober 2010, h. 135-144, diakses di http://karyailmiah.um.ac.id/index.php/disertasi /article/view/23829.

[8] Eka Puspa, Hariani Lilik Yudiono, (2017). Perilaku Ekonomi : Literasi Ekonomi, Kelompok Teman Sebaya, dan Kontrol Diri, Jurnal Riset Pendidikan Ekonomi (JRPE) e-

ISSN: 2540-9247. Volume: 5, Nomor: 1

[9] Faidah, Ning. 2018. Pengaruh Pengalaman Ekonomi, Kontrol Diri Serta Pendapatan Siswa Terhadap Perilaku Ekonomi Siswa Sma Di Kecamatan Pasir Belengkong Kabupaten Paser. Jurnal Ekonomi Pendidikan dan Kewirausahaan Vol. 6 No. 1 Hal 5982(online).

https://journal.unesa.ac.id/index.php/jepk.

[10] Jananti, N. (2014). Pengaruh Kepercayaan Diri, Budaya Lokal Dan Pendidikan Agama Terhadap Hasil Belajar Mata Pelajaran Ekonomi Siswa Kelas XI IPS SMA Negeri 1 Demak Tahun Ajaran 2013/2014. Economic Education Analysis Journal, $3(2)$

[11] Judy L. Postmus - Sara-Beth, (2013) Financial Literacy: Building Economic Empowerment with Survivors of Violence, , J Fam Econ Iss (2013) 34:275-284 DOI 10.1007/s10834-012- 9330-3

[12] Kennedy P. Brian. (2013). The Theory of Planned Behavior and Financial Literacy: A Predictive Model For Credit Card Debt? Dissertations. Paper 480.

[13] Latifah Abd.Raub , Mohammad Yusof , Mohd Shafie (2015) The Use of Contextual Learning to Promote Scientific Literacy in Science Classroom: From the Aspects of Higher Order Thinking Skills, ICES2015 Universiti Teknologi Malaysia, Johor Bahru,

Malaysia

[14] Nyomantrisna Herawati1, I Made Candiasa, (2018). Pengaruh Kualitas Pembelajaran Keuangan Dan Literasi Keuangan Terhadap Financial Self Efficacy Mahasiswa Akuntansi. JURNAL PENDIDIKAN EKONOMI, MANAJEMEN DAN KEUANGAN Vol. 2 No. 2 November 2018 DOI: 10.26740/Jpeka.V6n2.P115-128
[15] Partono Thomas, Kemal Budi Mulyono, Khasan Setiaji (2016) The Roles of Financial Knowledge, Motivation and Self Efficacy on the Influence of Financial Education toward Financial Literacy, Dinamika Pendidikan, http://journal.unnes.ac.id/nju/index.php/dp, DOI: 10.15294/dp.v11i2.8941

[16] Rafsanjani, M. A., Sholikhah, N., \& Prakoso, A. F. (2019). Does the "Idaman Jelita" Character of Universitas Negeri Surabaya Influence Students Economics Literacy? Dinamika Pendidikan, 14(2), 205-215. https://doi.org/10.15294/DP.V14I1.22

[17]Rheza Hafid Prastia, Sri Umi Mintarti W. (2017) Faktor-Faktor Yang Memengaruhi Perilaku Produktif Mahasiswa Fakultas Ekonomi Angkatan Tahun 2013. Jurnal Pendidikan: Teori, Penelitian, dan Pengembangan Volume: 2 Nomor: 2

[18]Saepuloh D, I Aisyah. (2020) PENGARUH ONLINE SHOP TERHADAP LITERASI EKONOMI SISWA SMA BERDASARKAN DEMOGRAFI. Pelita: Jurnal Penelitian Dan Karya Ilmiah.

DOI: $\quad$ Https://Doi.Org/10.33592/Pelita.Vol10.I $\underline{\text { ss } 1.329}$

[19]Saepuloh, D \& Rodiah, S (2020) Penerapan Pembelajaran Kooperatif Melalui Model Group Investigation Untuk Meningkatkan Literasi Ekonomi Siswa, Jurnal Pendidikan Ekonomi, 13(1), 30-41.

https://dx.doi.org/10.17977/um014v13i12020p 030

[20]Salamon, E. (2007). Scientific Literacy in Higher Education. Tamaratt Teaching Professorship.

[21] Sina, Peter Garlans. (2012). Analisis Literasi Ekonomi. Jurnal Ecnomia, volume 8, No.2, Oktober 2012

[22]Zohar, A., \& Dori, Y. J. (2009). Higher Order Thinking Skills and Low-Achieving Students : Are They Mutually Exclusive? Journal of the Learning Sciences, 37-41. 